\title{
Upaya Meningkatkan Kemampuan Mengenal Angka 1 sampai 10 melalui Permainan Kartu Angka pada Anak Usia Dini
}

\author{
Dias Syafitri Nurinta ${ }^{1}$, Yasniwarti ${ }^{2}$, Zaenal Muftie ${ }^{3}$ \\ 1,2,3Universitas Islam Negeri Sunan Gunung Djati \\ Jl. Cimencrang, Cimenerang, Gedebage, Kota Bandung, Jawa Barat 40292 \\ Email:dnurinta@gmail.com¹, yasniwartidjaluis@gmail.com², muftiez@ymail.com³
}

\begin{abstract}
Abstrak
Penelitian ini bertujuan untuk meningkatkan kemampuan mengenal angka 1 sampai 10 pada anak kelompok A RA Nurul Amal Ciguruwik Kecamatan Cileunyi Kabupaten Bandung melalui permainan kartu angka. Penelitian ini merupakan pennelitian tindakan kelas yang dilakukan secara kolaboratif antara peneliti dengan guru. Subjek dalam penelitian ini adalah 13 anak Kelompok A RA Nurul Amal yang terdiri dari 7 anak perempuan dan 6 anak laki-laki. Teknik pengumpulan data dilakukan dengan menggunakan observasi, unjuk kerja, dan dokumentasi. Teknik analisis data dilakukan secara deskriptif kualitatif dan kuantitatif. Hasil penelitian menunjukan peningkatan kemampuan anak mengenal angka 1 sampai 10 sebelum menggunakan permainan kartu angka memperoleh nilai rata-rata sebesar 50,64. Aktivitas guru pada siklus I menunjukkan persentase $76,47 \%$ kemudian pada siklus II meningkat menjadi $97,06 \%$. Aktivitas anak pada siklus I sebesar 72,65\% meningkat menjadi 95,3\% pada siklus II. Nilai rata-rata kemampuan mengenal angka 1 sampai 10 pada siklus I sebesar 64,74 ternyata mengalami peningkatan pada siklus II sebesar 78,85. Jadi peningkatan kemampuan mengenal angka sebelum dan sesudah dalam mengenal angka 1 sampai 10 sebesar 28,21 .
\end{abstract}

Kata kunci: alat permainan edukatif, anak usia dini, mengenal angka 1 sampai 10 , permainan kartu angka

\section{Abstract}

This study aims to improve the ability to recognize numbers 1 to 10 in children group $A$ RA Nurul Amal Ciguruwik in Cileunyi District, Bandung Regency through a number card game. This research is a classroom action research conducted collaboratively between researchers and teachers. The subjects in this study were 13 children of $A$ RA Nurul Amal Group consisting of 7 girls and 6 boys. Data collection techniques are carried out using observation, performance, and documentation. Data analysis techniques were 
carried out descriptively qualitative and quantitative. The results of the study showed that increasing the ability of children to know numbers 1 to 10 before using a number card game had an average score of 50.64. Teacher activity in the first cycle showed a percentage of $76.47 \%$ then in the second cycle increased to $97.06 \%$. Children's activity in cycle I was $72.65 \%$ increasing to $95.3 \%$ in cycle II. The average value of the ability to recognize numbers 1 to 10 in the first cycle of 64.74 turned out to have increased in the second cycle of 78.85. So increasing the ability to recognize numbers before and after recognizing numbers 1 to 10 is 28.21 .

Keywords: educational game tools, early childhood, recognize numbers 1 to 10, number card games

\section{Pendahuluan}

Anak usia dini merupakan masa keemasan (golden age) yang sangat penting bagi anak untuk mendapatkan pendidikan yang sesuai dengan umurnya. Pengalaman yang didapatkan dari lingkungannya, termasuk stimulasi yang diberikan akan berpengaruh besar bagi kehidupan anak di masa yang akan datang. Oleh karena itu, diperlukan upaya yang tepat agar tumbuh kembang anak dapat berlangsung secara optimal dengan memberikan kegiatan pendidikan dan pembelajaran yang sesuai dengan usia, kebutuhan, dan minat anak. Menurut UU No. 23 tahun 2002 pasal 9 ayat 1 tentang perlindungan anak, "setiap anak berhak memperoleh pendidikan dan pengajaran dalam rangka pengembangan pribadinya dan tingkat kecerdasannya sesuai dengan minat dan bakatnya" (Suyadi, 2011: 15).

Salah satu cara untuk meningkatkan tumbuh kembang anak dapat diperoleh dari pendidikan. Dalam Peraturan Menteri Pendidikan Nasional Republik Indonesia No. 58 Tahun 2009 tentang Standar Pendidikan Anak Usia Dini pasal 1 ayat (1) dinyatakan bahwa salah satu Standar Pendidikan Anak Usia Dini adalah Standar Tingkat Pencapaian Perkembangan. Tingkat Pencapaian Perkembangan menggambarkan pertumbuhan dan perkembangan yang diharapkan dicapai anak dalam rentang usia tertentu. Perkembangan anak yang dicapai merupakan integrasi dari aspek pemahaman nilai-nilai agama dan moral, fisik-motorik, kognitif, bahasa, dan sosial emosional.

Berdasarkan lingkup perkembangan kognitif, khususnya belajar pemecahan masalah, salah satu tingkat pencapaian perkembangan anak usia 4-5 tahun adalah mengenal konsep bilangan dan angka 1 sampai 10 (Lampiran 1 Permendikbud nomor 137 tahun 2014:26). Berdasarkan studi pendahuluan melalui observasi yang penulis lakukan di RA Nurul Amal kelompok A, penulis menemukan masih ada 10 anak yang 
belum mengetahui bentuk angka 1 sampai 10. Ada delapan anak masih belum memahami angka 1 sampai 10 dengan baik. Anak dapat menyebutkan angka sesuai dengan urutan bilangan angka dari 1 sampai 10 secara berurutan. Tetapi, pada dasarnya anak masih belum mampu mengenal bentuk angka dari itu sendiri dan masih banyak keliru dalam membedakan setiap bentuk dari angka-angka tersebut. Hal ini terlihat pada saat anak menyebutkan angka yang dituliskan pada papan tulis anak masih binggung dalam mengenal bentuk angka. Ada delapan anak yang masih terbalik dalam menyebutkan angka seperti 3, 5, 6, 8 dan 9.

Media pembelajaran yang digunakan untuk mengenalkan angka 1 sampai $10 \mathrm{di}$ RA Nurul Amal adalah dengan menggunakan media papan tulis dan media LKA sebagai sumber belajar. Berdasarkan pengamatan, diketahui bahwa pembelajaran masih berpusat pada guru, sehingga anak kurang aktif dalam menemukan pengalamannya sendiri dalam belajar. Selain itu, anak merasa jenuh serta bosan ketika pembelajaran berlangsung.

Untuk meningkatkan aktivitas anak dalam kegiatan pembelajaran serta meningkatkan kemampuan mengenal angka 1 sampai 10 perlu diupayakan sebuah perbaikan dalam pemberian stimulus. Salah satunya adalah bermain, karena dunia anak adalah dunianya bermain, belajarnya anak sebagian besar melalui permainan yang mereka lakukan. Sehingga, jika memisahkan bermain dan belajar sama halnya dengan memisahkan anak dari dunianya sendiri. Bermain adalah kegiatan yang sangat penting bagi anak. Menurut Suyanto (2005: 127) mengatakan bahwa esensi bermain meliputi perasaan menyenangkan, merdeka, bebas, memilih, dan merangsang anak terlibat aktif. Anak menghabiskan banyak waktunya hanya untuk bermain, apabila lima kebutuhannya dalam belajar dan bermain terpenuhi, maka anak akan berkembang secara optimal. Oleh karena itu, kegiatan anak selama bermain juga dapat memberikan pengetahuan dan pengalaman baru bagi anank, yang di dapat dari bahan dan alat yang dipersiapkan oleh guru agar anak menjadi lebih aktif dan kreatif. Kegiatan mengenalkan angka 1 sampai 10 diharapkan menggunakan alat permainan yang menarik, kreatif, dan menyenangkan bagi anak agar proses pembelajaran mudah untuk diterima oleh anak dengan menggunakan permainan kartu angka.

Pengertian kartu angka dalam Kamus Besar Bahasa Indonesia (2008: 628) kertas tebal berbentuk persegi untuk berbagai keperluan seperti karcis. Sedangkan Menurut Tadkirotun angka atau bilangan adalah lambang atau simbol yang merupakan suatu objek yang terdiri dari angka-angka (Syedara, 2016). Jadi dapat disimpulkan bahwa kartu angka adalah benda berbentuk persegi dan diberi nomor-nomor agar 
menarik diberi warna-warna yang cerah dan mencolok. Untuk melengkapi berbagai kegiatan pengenalan matematika untuk anak RA tersebut dapat menggunakan alat bermain/peraga maupun Alat Permainan Edukatif (APE).

Alat bermain/peraga maupun APE memiliki fungsi yang banyak dalam rangka proses pembentukan pribadi anak. Menurut Direktorat PADU, Depdiknas dalam Ali, dkk (2016:77) mendefinisikan alat permainan edukatif sebagai segala sesuatu yang dapat digunakan sebagai sarana atau peralatan untuk bermain yang mengandung nilai edukatif (pendidikan) dan dapat mengembangkan seluruh kemampuan anak. Permainan kartu angka ialah suatu aktivitas yang menyenangkan, memiliki aturan, dilakukan secara individu atau berkelompok yang menuntut partisipasi aktif baik secara fisik maupun psikis setiap anak. Alat permainan edukatif berupa kartu angka yaitu kartu berbentuk persegi bertuliskan angka 1 sampai 10 disertai gambar benda berwarna warni dan bervariasi yang jumlahnya sesuai dengan angka tersebut. Permainan kartu angka memiliki tujuan untuk membantu anak dalam menyebutkan bilangan, mengenal angka, mengenal konsep bilangan dengan benda-benda, mengenal bentuk, warna, serta melatih daya ingat anak.

Berdasarkan uraian latar belakang masalah di atas, maka rumusan masalah dalam penelitian ini adalah bagaimana kemampuan mengenal angka 1 sampai 10 sebelum menggunakan permainan kartu angka, proses penerapan permainan kartu angka, dan bagaimana kemampuan mengenal angka 1 sampai 10 kelompok A RA Nurul Amal Ciguruwik Kecamatan Cileunyi Kabupaten Bandung setelah menggunakan permainan kartu angka. Adapun tujuan yang hendak dicapai dalam penelitian ini untuk mengetahui kemampuan mengenal angka 1 sampai 10 sebelum menggunakan permainan kartu angka, proses penerapan permainan kartu angka, dan kemampuan mengenal angka 1 sampai 10 Kelompok A RA Nurul Amal Ciguruwik Kecamatan Cileunyi Kabupaten Bandung setelah menggunakan permainan kartu angka.

\section{Metodologi}

Metode yang digunakan dalam penelitian ini adalah metode penelitian tindakan kelas (PTK). Penelitian Tindakan Kelas (PTK) adalah penelitian tindakan (action research) yang dilakukan dengan tujuan memperbaiki mutu praktik pembelajaran dikelasnya (Arikunto, dkk, 2010:58). Penelitian ini terdiri dari dua siklus dengan setiap siklus nya terdiri dari perencanaan, pelaksanaan tindakan, observasi, dan refleksi. Subjek penelitian ini adalah anak kelompok A RA Nurul Amal, yaitu 13 anak yang terdiri dari 6 orang anak laki-laki dan 7 orang anak perempuan. 
Teknik pengumpulan data penelitian ini adalah unjuk kerja untuk memperoleh data kemampuan mengenal angka 1 sampai 10, observasi aktivitas guru dan anak, serta dokumentasi. Instrumen penelitian penelitian yang digunakan adalah unjuk kerja yang terdiri dari 3 indikator yaitu, menunjuk angka, meniru angka, dan menghubungkan angka dengan benda-benda sampai 10 (anak tidak disuruh menulis). Analisis data dilakukan melalui pengolahan temuan-temuan yang diperoleh selama proses penelitian berdasarkan instrumen yang digunakan dalam penelitian diantaranya sebagai berikut.

Untuk mengetahui tentang permainan kartu angka dapat meningkatkan kemampuan anak dalam mengenal angka 1 sampai 10 dapat dianalisis menggunakan data kuantitatif adalah sebagai berikut:

Nilai Kemampuan Mengenal Angka $=\frac{\text { Skor Perolehan }}{\text { Skor Maksimal }} \times 100$

(Hayati, 2013: 91)

Selanjutnya nilai tersebut diolah untuk menghasilkan nilai rata-rata anak yaitu dengan membagi jumlah seluruh skor yang diperoleh anak dibagi dengan jumlah anak. Adapun rumusnya ialah sebagai berikut:

$$
\mathrm{X}=\frac{\sum x}{\sum N}
$$

(Aqib, dkk, 2011: 40)

Keterangan:

$$
X=\text { Nilai rata-rata }
$$$$
\sum \mathrm{x}=\text { jumlah seluruh nilai siswa }
$$

$\sum \mathrm{N}=$ jumlah siswa

Untuk mengetahui bagaimana proses pembelajaran dengan menggunakan permainan kartu angka dalam mengenal angka 1 sampai 10 yaitu data diperoleh dari hasil lembar observasi aktivitas guru dan anak dianalisis menggunakan data deskriptif kualitatif dengan mendeskripsikan aktivitas yang dilakukan dalam proses pembelajaran setiap siklus.

$$
N P=\frac{R}{S M} \times 100 \%
$$

(Purwanto, 2008: 103)

\section{Keterangan :}

NP : Nilai persentase aktivitas yang dicari/dicapai

$$
\mathrm{R} \text { : Skor mentah yang diperoleh }
$$

SM : Skor maksimum ideal

100 : Bilangan tetap

Tabel 1. Kriteria Keterlaksanaan Aktivitas Pembelajaran 


\begin{tabular}{ccc}
\hline No & $\begin{array}{c}\text { Tingkat } \\
\text { Penguasaan }\end{array}$ & Predikat \\
\hline 1 & $86-100 \%$ & Sangat Baik \\
2 & $76-85 \%$ & Baik \\
3 & $60-75 \%$ & Cukup \\
4 & $55-59 \%$ & Kurang \\
5 & $\leq 54 \%$ & Kurang Sekali \\
\hline \multicolumn{4}{c}{ Sumber: Purwanto, 2008 }
\end{tabular}

\section{Hasil dan Diskusi}

Kemampuan akhir anak merupakan kemampuan dalam memahami pembelajaran setelah disampaikan pada penelitian ini adalah mengenal angka 1 sampai 10. Kemampuan tersebut dapat diketahui melalui unjuk kerja terakhir pada setiap siklus yang telah dilaksanakan.

Berdasarkan siklus yang telah dilakukan mulai dari siklus I dan siklus II, keterlibatan anak dalam proses pembelajaran berlangsung dengan aktif. Baik secara klasikal maupun kelompok. Berdasarkan penelitian siklus I rata-rata nilai aktivitas anak sebesar 76,47\% dengan kategori cukup, sedangkan pada siklus II mengalami peningkatan mencapai $95,3 \%$ dengan kategori sangat baik. Selain aktivitas anak, aktivitas guru juga mengalami peningkatan yang signifikan ke arah yang lebih baik dari siklus I ke siklus II. Hasil yang diperoleh pada siklus I mencapai $76,47 \%$ dengan kategori cukup, sedangkan pada siklus II mencapai 97,06\% dengan kategori sangat baik. Berdasarkan pemaparan tersebut bahwa aktivitas anak meningkat dari kategori cukup ke kategori sangat baik, hal sesuai dengan pendapat Harlock dalam Ali, dkk. (2016:7173) yang menjelaskan faktor yang mempengaruhi dari permainan anak diantaranya adalah kesehatan, perkembangan motorik, intelegensi, jenis kelamin, lingkungan dan taraf sosial ekonomi, serta alat permainan.

Dalam permainan kartu angka pada siklus I anak yang sakit hanya satu orang, sehingga dalam permainan kartu angka anak dapat mengikutinya dengan baik. Selain itu kemampuan intelegensi anak pun cukup bagus yaitu mampu memahami tugas yang dikerjakan dalam permainan kartu angka dengan baik, mendengarkan guru. Adapun faktor yang mempengaruhi jenis kelamin yaitu antara anak laki-laki dan perempuan. Pada anak laki-laki dalam mengerjakan permainan kartu angka hanya 3 orang anak yang tertarik melakukannya, sedangkan anak perempuan lebih tertarik untuk melakukan permainan kartu angka.

Tempat bermain pun sudah nyaman karena di dalam ruangan dan anak sudah tidak merasa asing lagi dengan permainan kartu angka, sehingga kegiatan bermain pun 
menjadi menyenangkan, aturan dan cara bermain pun tersampaikan dengan maksimal. Adapun status sosial di RA Nurul Amal tidak menjadi masalah karena semuanya dari kalangan menengah kebawah sehingga anak-anak dapat berbaur dengan baik bersama temannya. Hal ini juga dikarenakan guru melakukan tugasnya sebagai motivator dan fasilitator yang membantu anak dengan baik dalam proses pembelajaran. Alat permainan yang digunakan untuk permainan kartu angka pun sudah disediakan sehingga proses belajar mengajar menjadi lebih nyaman. Adapun peningkatan aktivitas guru pada setiap siklus dapat dilihat pada tabel berikut:

Tabel 2. Persentase Aktivitas Guru pada Setiap Siklus

\begin{tabular}{ccccc}
\hline No & Pembelajaran & \multicolumn{2}{c}{ Skor Rata-rata (\%) } \\
& & Terlaksana & $\begin{array}{c}\text { Tidak } \\
\text { Terlaksana }\end{array}$ & Keterangan \\
\hline 1. & Siklus I & $76,47 \%$ & $23,53 \%$ & Cukup \\
2. & Siklus II & $97,06 \%$ & $2.94 \%$ & Sangat Baik \\
\hline
\end{tabular}

Peningkatan Aktivitas Anak pada Setiap Siklus dapat dilihat pada tabel berikut.

Tabel 3. Persentase Aktivitas Anak pada Setiap Siklus

\begin{tabular}{ccccc}
\hline No & Pembelajaran & \multicolumn{2}{c}{ Skor Rata-rata (\%) } \\
& & Terlaksana & $\begin{array}{c}\text { Tidak } \\
\text { Terlaksana }\end{array}$ & Keterangan \\
\hline 1. & Siklus I & $76,47 \%$ & $23,53 \%$ & Cukup \\
2. & Siklus II & $95,3 \%$ & $4,7 \%$ & Sangat Baik \\
\hline
\end{tabular}

Kemampuan mengenal angka adalah konsep matematika yang sangat penting untuk dikuasai oleh anak. Dalam Permendiknas no 58 tahun 2009 menyatakan bahwa seharusnya anak usia 4-5 tahun sudah memiliki kemampuan dalam mengenal angka 1 sampai 10, dengan menggunakan media benda konkret ataupun tanpa media. Menurut Vygotsky dalam Tedjasaputra (2001:9) anak usia dini masih belum mampu untuk berpikir abstrak. Pembelajaran pada kemampuan kognitif merupakan hal yang sangat penting karena pengembangan kemampuan ini bertujuan untuk mengembangkan kemampuan berpikir untuk dapat mengolah perolehan belajarnya, dapat menemukan alternatif pemecahan masalah, membantu anak mengembangkan kemampuan logika matematikanya, mengelompokkan dan mempersiapkan pengembangan kemampuan berpikir teliti. Oleh sebab itu, kemampuan dasar matematika perlu dirangsang dan dikembangkan sejak dini. Karena akan menjadi dasar bagi penguasaan konsep-konsep matematika selanjutnya di jenjang pendidikan (formal) berikutnya. Kemampuan mengenal angka 1 sampai 10 anak kelompok A RA Nurul Amal Ciguruwik Kecamatan Cileunyi Kabupaten Bandung pada kemampuan awal atau sebelum dilakukan tindakan 
masih kurang baik yaitu kemampuan anak belum sesuai dengan tingkat pencapaian perkembangan anak yang terdapat dalam Permendiknas No. 58 tahun 2009 dengan nilai rata-rata yaitu sebesar 50,64 dikarenakan anak sebelum menggunakan permainan kartu angka yaitu dengan menggunakan media papan tulis, dan lembar kerja anak (LKA). Setelah menggunakan permainan kartu angka pada siklus I, kemampuan anak meningkat dengan nilai rata-rata 64,74. Kemampuan anak pada siklus II meningkat dengan nilai rata-rata 78,85 .

Tabel 2. Data Hasil Pra Tindakan, Siklus I dan Siklus II

\begin{tabular}{|c|c|c|c|c|}
\hline No & Nama Anak & Pra Tindakan & Siklus I & Siklus II \\
\hline 1. & AFR & 41,67 & 75 & 75 \\
\hline 2. & AK & 41,67 & 75 & 75 \\
\hline 3. & AKU & 75 & 83,33 & 100 \\
\hline 4. & ADA & 75 & 100 & 100 \\
\hline 5. & DDA & 25 & 41,67 & 50 \\
\hline 6. & FAS & 75 & 91,67 & 100 \\
\hline 7. & HS & 41,67 & 66,67 & 75 \\
\hline 8. & JTU & 50 & 66,67 & 75 \\
\hline 9. & KAS & 66,67 & 0 & 83,33 \\
\hline 10. & MAM & 66,67 & 75 & 91,67 \\
\hline 11. & NSN & 33,33 & 58,33 & 58,33 \\
\hline 12. & $\mathrm{~N}$ & 41,67 & 66,67 & 83,33 \\
\hline \multirow[t]{3}{*}{13.} & RMF & 25 & 41,67 & 58,33 \\
\hline & Jumlah & 658,35 & 841,68 & 1024,99 \\
\hline & Rata-Rata & 50,64 & 64,74 & 78,85 \\
\hline
\end{tabular}

Tabel 2 di atas merupakan hasil nilai rata-rata kemampuan belajar anak pada pra tindakan, siklus I dan siklus II, untuk mempermudah melihat peningkatan kemampuan anak dalam mengenal angka 1 sampai 10 dapat dilihat pada gambar grafik dibawah ini.

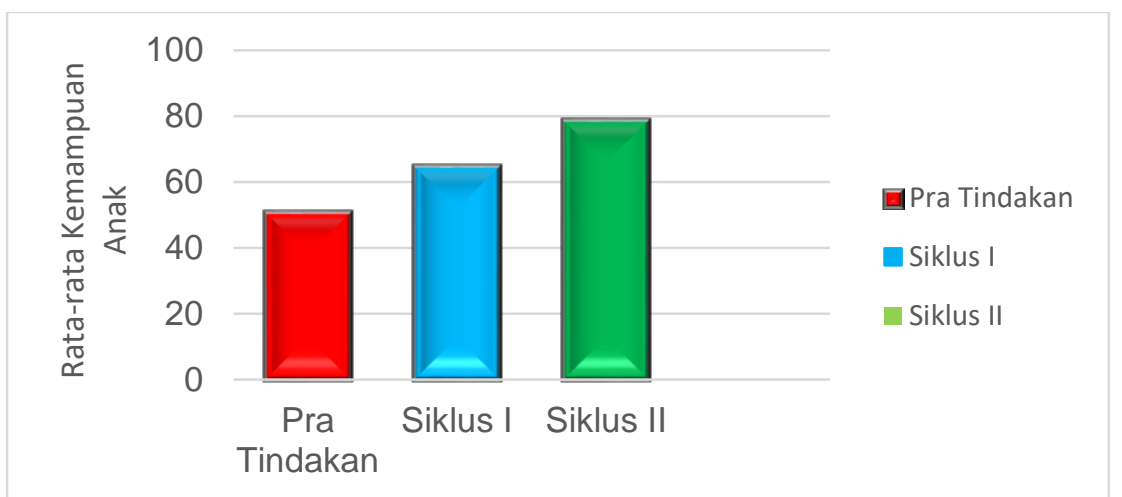

Gambar 1. Peningkatan Kemampuan Anak sebelum Tindakan sampai setelah Tindakan

Beradasarkan Gambar 1 di atas bahwa peningkatan kemampuan anak dalam mengenal angka 1 sampai 10 melalui permainan kartu angka dapat meningkat, hal 
tersebut sesuai dengan pendapat Suyanto (2005:127) bahwa pembelajaran di RA harus menerapkan esensi bermain yang meliputi perasaan menyenangkan, merdeka, bebas, memilih, dan merangsang anak terlibat aktif. Namun, dalam pelaksanaan tindakan siklus I suasana kelas masih kurang kondusif dan sebagian anak belum fokus ketika mengikuti pembelajaran mengenal angka 1 sampai 10 melalui permainan kartu angka. Hal ini disebabkan hanya dua orang anak yang maju bergantian ke depan kelas.

Pada siklus II anak menjadi antusias, terlibat aktif, dan fokus dalam mengikuti pembelajara mengenal angka 1 sampai 10 melalui permainan kartu angka, serta suasana kelas sudah semakin kondusif. Hal ini dikarenakan permainan kartu angka dilakukan secara bersama-sama oleh semua anak. Hal itu serupa dengan pendapat Dorothy, Roy, dan Simon dalam Yus (2005: 23) bermain terdiri dari beberapa jenis, yaitu bermain bebas, bermain dengan bimbingan, dan bermain dengan diarahkan. Ada juga yang melihat bermain dari jumlah anak yang terlihat. Ada bermain sendiri, berdua, dan beramai-ramai. Sehingga pembelajaran menjadi sangat menyenangkan dan tidak membosankan. Alat permainan edukatif (APE) yang diguanakan dalam pembelajaran mengenal angka 1 sampai 10 adalah kartu angka. Kartu angka merupakan alat bermain yang digunakan untuk menunjang kelancaran penyelenggaraan kegiatan belajar mengajar dan bertujuan untuk mempermudah anak dalam mengenal angka 1 sampai 10. Pendapat tersebut sesuai yang dinyatakan Menurut Direktorat PADU, Depdiknas dalam Ali, dkk (2016:77) mendefinisikan alat permainan edukatif sebagai segala sesuatu yang dapat digunakan sebagai sarana atau peralatan untuk bermain yang mengandung nilai edukatif (pendidikan) dan dapat mengembangkan kemampuan anak.

Kartu angka yang bertuliskan angka 1 sampai 10 mempunyai variasi gambar, dan berwarna-warni dirancang untuk meningkatkan aspek perkembangan kognitif anak terutama dalam kemampuan mengenal angka 1 sampai 10 . Hal itu sesuai dengan pendapat Ali, dkk (2016:78) bahwa alat permainan edukatif (APE) merupakan bagian yang tak terpisahkan dalam pembelajaran anak usia dini. Melalui APE, pendidik maupun orang tua dapat mengembangkan aspek-aspek perkembangan pada anak secara efektif dan menyenangkan. Sehingga anak dapat berkembang secara optimal. Adapun aspek yang dapat dikembangkan adalah aspek fisik (motorik halus dan kasar), emosi, sosial, bahasa, kognitif, dan moral.

Pada dasarnya pengembangan kemampuan mengenal angka merupakan salah satu aspek perkembangan kognitif yang perlu dikembangkan pada anak usia dini. Kemampuan mengenal angka pada anak kelompok A di RA Nurul Amal Ciguruwik Kecamatan Cileunyi Kabupaten Bandung mendapatkan nilai rata-rata kriteria 
berkembang sesuai harapan. Hasil penelitian ini terbukti sesuai dengan yang dinyatakan pada pedoman pengembangan pembelajaran di Taman Kanak-kanak dalam Kurikulum Tahun 2009, bahwa Standar Tingkat Pencapaian Perkembangan untuk anak kelompok A usia 4-5 tahun dalam konsep mengenal angka, seharusnya anak sudah mampu untuk menunjuk angka 1-10, meniru angka 1-10 dan menghubungkan/memasangkan angka dengan benda-benda sampai 10 (anak tidak disuruh menulis).

\section{Penutup}

Berdasarkan dari hasil kegiatan pembelajaran yang telah dilakukan dengan menggunakan dua siklus dan berdasarkan hasil penelitian dan pembahasan yang telah dilakukan dapat disimpulkan bahwa kemampuan mengenal angka 1 sampai 10 sebelum menggunakan kartu angka memperoleh nilai rata-rata sebesar 50,64. Hal ini dilihat pada observasi awal pada kegiatan penelitian pra tindakan. Terlihat anak masih belum memahami bentuk angka, dikarenakan anak sebelum menggunakan permainan kartu angka yaitu dengan menggunakan media papan tulis, dan lembar kerja anak (LKA). Penerapan permainan kartu angka pada mengenenal angka 1 sampai 10 di kelompok $A$ RA Nurul Amal tergolong aktif. Aktivitas guru pada siklus I sebesar 76,47\% dengan kategori cukup dan mengalami peningkatan pada siklus II yaitu sebesar 97,06 dengan ketegori sangat baik. Sedangkan aktivitas anak pada siklus I sebesar 76,47\% dengan kategori cukup dan meningkat pada siklus II sebesar 95,3\% dengan kategori sangat baik. Kemampuan anak kelompok A RA Nurul Amal setelah menggunakan permainan kartu angka, mengalami peningkatan. Pada siklus I nilai rata-rata kemampuan anak sebesar 64,74 dan pada siklus II mencapai rata-rata 78,85.

Berdasarkan temuan hasil penelitian ini maka disarankan kepada para guru di Raudhatul Athfal bahwa permainan kartu angka dapat dijadikan alternatif pembelajaran di RA agar meningkatkan atau mengembangkan kemampuan mengenal angka 1 sampai 10. Bagi peneliti selanjutnya, penelitian mengenai cara meningkatkan kemampuan mengenal angka 1 sampai 10 melalui permainan kartu angka ini masih banyak kekurangan yang harus diperbaiki. Selain dapat mengembangkan aspek perkembangan kognitif khususnya pada kemampuan mengenal angka 1 sampai 10, ternyata juga dapat mengembangkan kemampuan mengenal warna, bentuk, serta melatih daya ingat anak. Sehingga, dapat dijadikan alternatif bagi peneliti lain untuk mengembangkan aspek perkembangan lainnya.

\section{Daftar Pustaka}


Aqib, Z , dkk. (2011). Penelitian Tindakan Kelas. Bandung: Yrama Widya.

Hayati, T. (2013). Evaluasi Pembelajaran. Bandung: CV. Insan Mandiri.

Kamus Besar Bahasa Indonesia. (2008). Jakarta: Pusat Bahasa Departemen Pendidikan Nasional.

Ali, N R, dkk. (2016). Perkembangan \& Alat Permainan Educatif Anak Usia Dini. Yogyakarta: Editie Pustaka.

Permendiknas No. 58 Tahun 2009 Tentang Standar Pendidikan Anak Usia Dini.

Permendikbud No. 137 Tahun 2014 Tentang Standar Nasional Pendidikan Anak Usia Dini.

Purwanto, N. (2008). Prinsip-Prinsip dan Teknik Evaluasi Pengajaran. Bandung: PT Remaja Rosdakarya.

Arikunto, S, dkk. (2010). Penelitian Tindakan Kelas. Jakarta: Bumi Aksara.

Suyadi. (2011). Manajemen PAUD. Yogyakarta: Pustaka Pelajar.

Suyanto, S. (2005). Dasar-dasar Pendidikan Anak Usia Dini. Yogyakarta: Hikayat Publishing.

Syedara. (2016). Pengertian Angka. http://www.syedara.com/2016/10/pengertianangka/ (diakses pada tanggal 1 Agustus 2018).

Tedjasaputra, M S. (2001). Bermain, Mainan, dan Permainan. Jakarta: PT Grasindo.

Undang - Undang Republik Indonesia No. 20 Tahun 2003 Tentang Sistem Pendidikan Nasional.

Yus, A. (2005). Penilaian Perkembangan Belajar Anak Taman Kanak-Kanak. Jakarta: Kencana

\section{Biodata Penulis}

Dias Syafitri Nurinta di Jakarta pada 15 Agustus 1996, telah menyelesaikan pendidikan S1 pada Program Studi Pendidikan Islam Anak Usia Dini di Fakultas Tarbiyah dan Keguruan UIN Sunan Gunung Djati Bandung (2018).

Yasniwarti di Padang 01 Januari 1954, telah menyelesaikan pendidikan S1 Jurusan Pendidikan Bahasa Arab di Fakultas Tarbiyah dan Keguruan IAIN Sunan Gunung Djati Bandung (1990), S2 Jurusan Pendidikan Bahasa Indonesia Universitas Pendidikan Indonesia (2003). Merupakan dosen di Program Studi Pedidikan Islam Anak Usia Dini Fakultas Tarbiyah dan Keguruan UIN Sunan Gunung Djati Bandung. Bidang yang 
ditekuni antara lain Bahasa Indonesia, dan Pengembangan Kemampuan Berbahasa Anak Usia Dini.

Zaenal Muftie di Subang pada 30 Oktober 1978, telah menyelesaikan pendidikan S1 Jurusan Pendidikan Agama Islam di Fakultas Tarbiyah dan Keguruan UIN Sunan Gunung Djati Bandung, S2 Program Studi Pendidikan Islam UIN Sunan Gunung Djati Bandung. Merupakan dosen di Program Studi Pendidikan Islam Anak Usia Dini Fakultas Tarbiyah dan Keguruan UIN Sunan Gunung Djati Bandung. Bidang yang ditekuni antara lain Pendidikan Agama Islam di RA, IImu Tauhid, dan IImu Akhlak. 